\title{
THE ENGINEERING OF LIGHT DISTRIBUTION ENHANCEMENT THROUGH PRUNING MANAGEMENT TOWARDS THE PRODUCTION OF COCOA TREE (THEOBROMA CACAO L.) IN SOPPENG REGENCY, SOUTH SULAWESI OF INDONESIA
}

\author{
Fatmawati $^{*}$ \\ Faculty of Agriculture, University of Islam Makassar, Indonesia \\ Ariffin, Yudo Tyasmoro S., Sulistyono R. \\ Faculty of Agriculture, University of Brawijaya, Indonesia \\ *E-mail: fatmawatimahmud.dty@uim-makassar.ac.id
}

\begin{abstract}
Cocoa (Theobroma cacao L.) is a mainstay crop in South Sulawesi and Soppeng Regency is one of the cocoa producing regions that contribute to the cocoa industry in Indonesia. This research was conducted in Salaonro Village, Lilirilau Sub-District, Soppeng Regency, South Sulawesi from March to November 2018, using a two-factor factorial design. The first factor is the type of shade loving plants consisting of: New Guinea Teak (Vitex coffasus) (N1) Gliricidia (Gliricidia sepium) (N2) and White Teak (Tectona grandis L.) (N3), while the second factor is pruning, consisting of (P0) without pruning, (P1) one pruning in a month, (P2) one pruning in two months. The results showed that the shade loving plant species had an effect to the weather aspect, which was only on the intensity of sunlight above the canopy at 24 msp, namely the white teak (N3). The average pruning time had an effect on the weather aspect at $16 \mathrm{msp}$ and $20 \mathrm{msp}$ and one pruning in two months (P2) had a greater effect than one pruning in a month (P1) as well as no pruning (P0). The shade loving plant species had an effect on the physiological aspect namely leaf moisture. The highest leaf moisture value was $\mathrm{N} 1>\mathrm{N} 3>\mathrm{N} 2$, respectively, while pruning time had an effect on leaf temperature $\mathrm{P} 2>\mathrm{P} 1>\mathrm{P} 0$. For the agronomic aspects, both shade loving trees and pruning time had an effect on the number of fruits $\mathrm{N} 3>\mathrm{N} 2>\mathrm{N} 1$ and $\mathrm{P} 2>\mathrm{P} 1>\mathrm{PO}$ and for fresh weight of and dry weight of 100 seeds also had an effect. The one pruning in two months (P2) had a positive effect compared to other treatments, namely (P1) and (P0). The interaction between shade loving tree species and pruning time on the weather aspect was soil temperature at $16 \mathrm{msp}$ where the treatment (N3P2) of white teak with one pruning in two months had the lowest soil temperature value (26.83) compared to other treatment interactions. Furthermore, interaction between shade loving tree species and pruning time on physiological aspects, namely the rate of photosynthesis, the highest photosynthesis rate in the treatment was N3P0> N2P1> N2P2, respectively.
\end{abstract}

\section{KEY WORDS}

Engineering, light distribution, pruning, cocoa, production.

Cocoa (Theobroma cacao L.) is one of the commodities in Indonesia which is a mainstay commodity of South Sulawesi. Cocoa plays an important role in the national economy, such as, employment opportunities, a source of income for farmers, and foreign exchange for the country. Indonesia is the third greatest exporter of cocoa in the world after Ghana and Ivory Coast. The national cocoa production in 2013, with an area of 1,740,612 ha, was only 0.414 tons ha-1 (Statistics of Indonesian Plantation, 2014). The world cocoa demand is increasing from year to year. The International Cocoa Organization (ICCO) estimates that world cocoa production in 2017 will reach 4.50 million tons, while consumption will reach 4.51 million tons, so that production is predicted to be a deficit of approximately 10 thousand tons per year. Indonesia was ranked first in Asia in production with a contribution reaching 9.28 percent (ICCO, 2015; Suryani and Zulfebransyah, 2007). 
The low production of cocoa, as the case in South Sulawesi is due to the planting was not conducted in suitable areas, such as areas that have a dry season of 4-7 months. In addition to reducing the productivity, dry season also reduces plant resistance to pests, and in very severe conditions, can even cause death. The impact of drought will be more severe with minimal maintenance carried out by farmers such as limited shade loving trees. Besides the use of shade loving trees is an effort to regulate solar radiation, air temperature, humidity, and the rate of humidity loss through transpiration or evaporation, the amount of solar energy that can be captured by plant canopies is very diverse and depends on several factors including: Planting systems, plant population and growth rate. Cacao is a C3 plant that needs shade loving trees for its growth. However, cocoa still needs optimum light intensity for normal growth and development. Young cocoa plants need light intensity around $25-60 \%$ of the full intensity (Abdoellah and Soedarsono, 1996). Meanwhile, according to (Prawoto, 2012), the intensity of $50-70 \%$ light provides the highest production for adult cocoa plants.

Plant preservation engineering is one way to improve plant growth environment. Environmental balance can be influenced by plant populations in cocoa plantations with various types of shade loving tree. This arises a thought that the level of population and certain types of shade loving trees will provide the intensity of sunlight received by cocoa plants which gives a good effect on the production and quality of cocoa, as well as the pruning time. Cocoa pruning is intended to regulate the appropriate micro-climate for flower and fruit growth or to regulate the number and distribution of leaves. Some research showed that regular pruning can provide better yields, increase production and maintain the economic life of plants. In general, pruning aims to: get balanced canopy growth, reduce humidity to protect from pests and diseases, improve air circulation around plants, facilitate the implementation of harvesting and maintenance, get high production, expand the surface of the assimilation, and stimulate flowering and fruiting which is caused by vegetative and generative balance (Lopez et al., 2016). In addition, pruning will improve the process of getting the sunlight which plays an important role for the survival of plant physiology, especially for photosynthesis, respiration and transpiration. The rate of photosynthesis can be approached by counting the number of leaves and measuring the rate of $\mathrm{CO} 2$ absorption per unit area of the leaf. The number of leaves expressed in LAI (Leaf Area Index). According to Alvim et.al, (1972) the optimum LAl for adult cocoa plants is about 3.7-5.7, which is equivalent to the production of assimilates of $3.5-5.0 \mathrm{mg} / \mathrm{dm}^{2} /$ day or $12.8-18.2$ tons of dried material/hectare/year. Angela (2011) in Bailhaqi et al (2015) shows that the number of fruits in cacao plants that were not pruned decreased from 209 to 187, while in the pruned plants the number of fruits increased from 116 to 127 . Pruning aims to increase productivity and preserve plants so that it can have higher production, and improve the microclimate contained in plant areas.

This research aimed to determine the type of shade loving plants, plant preservation engineering and micro-climate components that have effect on cocoa production. The results of this research are expected to be a reference and comparison in future studies and as information for farmers in particular, and the community in general, that certain types of shade loving plants will provide optimal sunlight intensity and pruning time aimed to achieve efficient utilization of sunlight and improve the micro-climate contained around plants, and can increase cocoa production.

\section{METHODS OF RESEARCH}

The determination of the location and sample of the research was carried out by conducting sampling in three sub-districts which had been measured for their weather aspects and were selected purposely for the location of the cocoa plantations which had criteria in accordance with the research object. The research was located proportionally in cocoa plantations in Salaonro Village, Lilirilau Sub-District, Soppeng Regency.

By using a two-factor factorial design, the first factor in each group, Group I with New Guinea Teak as shade loving trees (N1), Group II with Gliciridia as shade loving trees (N2) and Group III with White Teak as shade loving trees (N3). The second factor in each 
plantation (research location) was chosen randomly for cocoa plants that have the same age and canopy shape at the time of pruning treatment which consisted of three levels, namely: $\mathrm{P} 0=$ No Trimming, $\mathrm{P} 1=$ One pruning in a month, $\mathrm{P} 2=$ One pruning in two months

So that there were 9 treatment combinations each treatment consisted of two plants, thus, the number of plants needed was 18 plants in each group, so that, it would need 54 cocoa plants. The field research was conducted using measurements of weather aspects, physiological aspects and agronomic aspects March 2018 to November 2018.

The data collected in this research were in the form of primary and secondary data. Primary data aimed to evaluate the problems of farmers in the field in an effort to increase cocoa productivity by direct research methods in the field for six months by measuring; (1) Weather aspects include the intensity of sunlight above and under the canopy, air humidity, air temperature and soil temperature; (2) physiological aspects include, photosynthesis rate, leaf temperature, leaf humidity, chlorophyll index and leaf area, (3) agronomic aspects include the number of fruits, fresh weight of 100 seeds, dry weight 100 seeds. The secondary data as supporting data were collected from the Sub-District Office, Agriculture Service Office, Plantation Office of Soppeng Regency and South Sulawesi Province, Statistics Office of Soppeng Regency, The Class I Meteorological, Climatological and Geophysical Agency of Maros, and other related offices and institutions/agencies.

The data obtained were analyzed using ANOVA on weather aspects, physiological aspects and agronomic aspects, as follows: (1) Weather aspects include the intensity of sunlight above and under the canopy, air humidity, air temperature and soil temperature; (2) physiological aspects include, photosynthesis rate, leaf temperature, leaf humidity, chlorophyll index and leaf area, (3) agronomic aspects include the number of fruits, fresh weight of 100 seeds, dry weight 100 seeds, and if there was a real effect then it was continued with BNJ follow-up tests at the level of $\alpha=0.05$ and 0.01 .

Soppeng Regency is one of the Regencies in South Sulawesi, which is approximately $150 \mathrm{~km}$ north of the Province of South Sulawesi. Geographically, it is located between $04^{\circ}$ 20' 21.4" LS $4^{\circ} 32$ LU and $119^{\circ} 57^{\prime} 47,4^{\prime \prime}$ E.

The area and production and productivity of cocoa plantations in South Sulawesi last five years, from 2014-2018, varied during the five-year period, as seen in Table 1

Table 1 - The data of land area, production and productivity of Cocoa in South Sulawesi in the period of 2014-2018

\begin{tabular}{cccc}
\hline Year & $\begin{array}{c}\text { Cocoa Land Area } \\
\text { (ha) }\end{array}$ & $\begin{array}{c}\text { Production } \\
\text { (Ton) }\end{array}$ & $\begin{array}{c}\text { Productivity } \\
\text { (Kg/ha) }\end{array}$ \\
\hline 2014 & 246,233 & 143,237 & 807 \\
2015 & 243,778 & 143,073 & 811 \\
2016 & 240,073 & 152,972 & 868 \\
2017 & 240,374 & 175,860 & 1,004 \\
2018 & 240,727 & 200,000 & 1,055 \\
\hline
\end{tabular}

Source: South Sulawesi Plantation Service Data.

From Table 1 above, it can be seen that the productivity of cocoa plants has increased every year, where 2018 had the highest productivity of $1,055 \mathrm{~kg} / \mathrm{ha}$. This was still far from the targeted results (South Sulawesi Plantation Office, 2018). Meanwhile, according to data from (Indonesian Plantation Statistics, 2014), the national cocoa production in 2013 with an area of $1,740,612$ ha of production was only 0.414 tons ha ${ }^{-1}$. According to Nasaruddin et.al., (2009), the potential yield of superior cocoa clones could reach 4.0 tons $\mathrm{ha}^{-1} \mathrm{yr}^{-1}$ in a study conducted with optimal environmental conditions.

According to Schmidth and Forgusson Classification, Soppeng Regency is included in area with climate type $C$ with an average annual rainfall of $1,428 \mathrm{~mm}$. The rainy season is in the period of April to September, while the dry season is in the period of October to March. The average air temperature ranges from $24 \mathrm{oC}$ to $30 \mathrm{oC}$ and the average humidity $(\mathrm{RH} \%)$ is $68 \%$. The annual rainfall for five years in Soppeng District, Lilirilau District can be seen in Figure. 1 
The distribution of annual rainfall over the past 5 years showed the highest amount of rainfall was recorded in $2016(2432 \mathrm{~mm})$ and the lowest average rainfall was recorded in $2015(1175 \mathrm{~mm})$. The distribution of annual rainfall $(\mathrm{mm})$ in the period of $2014-2018$ can be seen in Figure 1.

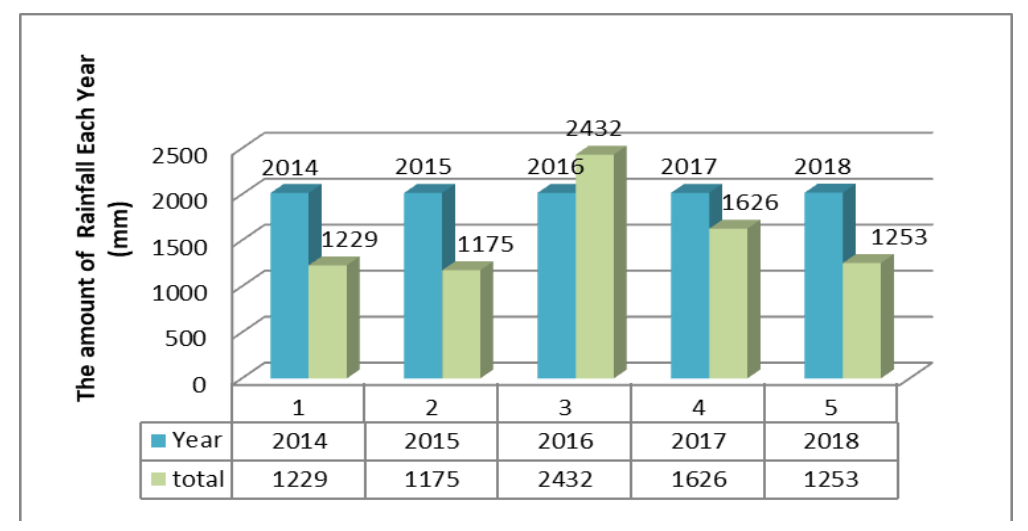

Figure 1 - The Distribution of Annual Rainfall ( $\mathrm{mm}$ ) in Lilirilau Sub-District, Soppeng Regency, South Sulawesi in the period of 2014-2018

\section{RESULTS AND DISCUSSION}

The results of BNJ test in Table 2 and 3 below show that the intensity of sunlight above and under the canopy does not show any significant difference to the three species of shade loving trees at all observations except at $24 \mathrm{msp}$, instead the three types of shade loving plants have a significant effect on the intensity of sunlight above the canopy. The highest intensities were in (N3), (N2) and (N1). White Teak (N3) had a significant effect at 24 msp. Whereas at $8 \mathrm{msp}, 12 \mathrm{msp}, 16 \mathrm{msp}$ and $20 \mathrm{msp}$, the pruning time was significantly different from the intensity of sunlight above and under the canopy.

Table 2 - The Average of Sunlight Intensity (Lux) Above the Canopy on Three Types of Shade Loving Trees and Pruning Time on Cocoa Plants

\begin{tabular}{ccccccc}
\hline Treatment & \multicolumn{5}{c}{ Average } \\
\cline { 2 - 7 } & $4 \mathrm{msp}$ & $8 \mathrm{msp}$ & $12 \mathrm{msp}$ & $16 \mathrm{msp}$ & $20 \mathrm{msp}$ & $24 \mathrm{msp}$ \\
\hline $\mathrm{N} 1$ & $5,746.1 \mathrm{tn}$ & $7,303.9 \mathrm{tn}$ & $6,507.5 \mathrm{tn}$ & $5,931.7 \mathrm{tn}$ & $6,271.6 \mathrm{tn}$ & $5,444.4 \mathrm{ab}$ \\
$\mathrm{N} 2$ & $5,995.0 \mathrm{tn}$ & $7,126.6 \mathrm{tn}$ & $6,507.5 \mathrm{tn}$ & $4,886.1 \mathrm{tn}$ & $5,707.7 \mathrm{tn}$ & $5,202.2 \mathrm{~b}$ \\
$\mathrm{~N} 3$ & $5,353.3 \mathrm{tn}$ & $7,681.1 \mathrm{tn}$ & $6,507.5 \mathrm{tn}$ & $5,417.2 \mathrm{tn}$ & $1,902.5 \mathrm{tn}$ & $7,008.3 \mathrm{a}$ \\
\hline BNJ 0,01 & tn & tn & tn & tn & tn & tn \\
0,05 & tn & tn & tn & tn & tn & $1,565.5$ \\
\hline P0 & $5,906.1 \mathrm{tn}$ & $9,443.3 \mathrm{a}$ & $6,768.3 \mathrm{tn}$ & $5,969.5 \mathrm{a}$ & $5,300.5 \mathrm{a}$ & $6,750.0 \mathrm{tn}$ \\
$\mathrm{P} 1$ & $5,553.9 \mathrm{tn}$ & $6,910.5 \mathrm{~b}$ & $6,172.5 \mathrm{tn}$ & $5,833.3 \mathrm{a}$ & $4,270.7 \mathrm{~b}$ & $5,142.2 \mathrm{tn}$ \\
$\mathrm{P} 2$ & $5,634.4 \mathrm{tn}$ & $5,575.7 \mathrm{~b}$ & $6,581.6 \mathrm{tn}$ & $4,432.2 \mathrm{~b}$ & $4,310.7 \mathrm{a}$ & $5,762.7 \mathrm{tn}$ \\
\hline BNJ 0,01 & tn & $1,922.3$ & tn & tn & tn & tn \\
0,05 & tn & tn & tn & $1,359.8$ & $1,501.2$ & tn \\
\hline
\end{tabular}

Note: The numbers followed by different letters mean significant difference at the $\alpha=0.05$ and highly significant difference at $\alpha=0.01$. N1 = New Guinea Teak, N2 = Gliciridia, N3 = White Teak $P 0=$ No Pruning, P1 = One Pruning a month, $P 2=$ One pruning in two months, $t n=$ not significantly different, $m s p=$ weeks after treatment.

Shade loving trees will determine the intensity of sunlight entering the canopy, because the architecture and density of the canopy as well as the life cycle of the shade loving plants vary - this becomes important to know. Besides, the most important thing is the rainfall pattern. According to (Atanda, 1972), the distribution of rainfall is more important than the amount of rainfall. The monthly rainfall was only $24 \mathrm{msp}(55 \mathrm{~mm})$ at the time of observation. Figure 1 showed that the eastern coast of South Sulawesi entered the dry season at that month, it is assumed that one of the factors that has great effect on the white teak which has a life cycle on the dry season will shed its leaves to reduce evaporation, so that the intensity 
of sunlight has the effect on, as well as on the New Guinea Teak (N1) and Gliciridia (N2). Meanwhile, according to (Fatmawati et al., 2018) that the intensity of sunlight reaching the cocoa plant is influenced by variations in the type of shade. Different types of shade variations give different values of the intensity of sunlight intercepted.

The treatment (P0) differed significantly from (P1) and (P2). At $16 \mathrm{msp},(\mathrm{P} 0)$ and (P1) were significantly different from (P2), and at $20 \mathrm{msp}(\mathrm{P} 0)$ and (P2) were not different but differed from (P1). Furthermore, it can be seen that (P0) shows the value of sunlight intensity above the top canopy at $8 \mathrm{msp}$ of $(9,443.3)$, and (P1) shows the value of sunlight intensity above the bottom canopy of $(4,270.7)$ at $20 \mathrm{msp}$. The one pruning in two months (P2) treatment have an effect on both the intensity of sunlight above and under canopy of the cocoa trees. It is suspected that One pruning in two months (P2) treatment can reduce the internal competition of plants so that the use of food substances will be more effective than those with one pruning a month (P1) treatment as pruning is done more often than expected, so that the leaves are reduced as well as the photosynthesis process and assimilation. obtained from the process of photosynthesis is reduced as well as plants that are not pruned (P0) the leaves are more lush and shade each other so that they co-op and the intensity of sunlight on the canopy is higher and the less can be continued. Pruning will provide a lot of sunlight penetration. According to (Vernon and Sunderam, 1972), controlling the growth and density of cocoa trees, as well as increasing aeration and penetration of light are needed to increase fruit production. Meanwhile, according to (Siregar et al 2003), to form a balance between the canopy and roots to maintain the economic life of plants, pruning needs to be done with the aim of increasing production

Table 3 below shows that the intensity of sunlight under the canopy does not show any significant difference in the three loving shade species and pruning time at $4 \mathrm{msp}$ and 24 $\mathrm{msp}$, but at $8 \mathrm{msp}$ and $20 \mathrm{msp}$, it shows that pruning time is significantly different from sunlight intensity under the canopy and differ significantly at $12 \mathrm{msp}, 16 \mathrm{msp}$, and $20 \mathrm{msp}$. (P2) shows the value of sunlight intensity under the top canopy at $20 \mathrm{msp}(1,490.5)$ is significantly different from (P0) and (P1) and (P0) shows the value of sunlight intensity under the lowest canopy (771.4) at $16 \mathrm{msp}$ is significantly different from (P1) and (P2).

Table 3 - The Average Sunlight Intensity (Lux) under the Canopy on Three Types of Shade Loving Trees and Pruning Time on Cocoa Plants

\begin{tabular}{ccccccc}
\hline Treatment & \multicolumn{7}{c}{ Average } \\
\cline { 2 - 7 } & $4 \mathrm{msp}$ & $8 \mathrm{msp}$ & $12 \mathrm{msp}$ & $16 \mathrm{msp}$ & $20 \mathrm{msp}$ & $24 \mathrm{msp}$ \\
\hline $\mathrm{N} 1$ & $389.8 \mathrm{tn}$ & $933.4 \mathrm{tn}$ & $1,113.5 \mathrm{tn}$ & $1,120.0 \mathrm{tn}$ & $1,274.1 \mathrm{tn}$ & $1,009.7 \mathrm{tn}$ \\
$\mathrm{N} 2$ & $416.1 \mathrm{tn}$ & $874.5 \mathrm{tn}$ & $1,110.1 \mathrm{tn}$ & $1,063.6 \mathrm{tn}$ & $1,260.7 \mathrm{tn}$ & $953.8 \mathrm{tn}$ \\
$\mathrm{N} 3$ & $382.1 \mathrm{tn}$ & $845.0 \mathrm{tn}$ & $1,088.5 \mathrm{tn}$ & $1,082.3 \mathrm{tn}$ & $1,328.2 \mathrm{tn}$ & $1,032.9 \mathrm{tn}$ \\
\hline BNJ 0,01 & tn & tn & tn & tn & tn & tn \\
0,05 & tn & tn & tn & tn & tn & tn \\
\hline P0 & $385.0 \mathrm{tn}$ & $976.1 \mathrm{a}$ & $1,364.5 \mathrm{a}$ & $771.4 \mathrm{~b}$ & $1,149.5 \mathrm{~b}$ & $1,017.8 \mathrm{tn}$ \\
$\mathrm{P} 1$ & $416.7 \mathrm{tn}$ & $841.2 \mathrm{~b}$ & $910.6 \mathrm{~b}$ & $1,143.2 \mathrm{a}$ & $1,223.1 \mathrm{~b}$ & $1,020.6 \mathrm{tn}$ \\
$\mathrm{P} 2$ & $386.3 \mathrm{tn}$ & $835.7 \mathrm{~b}$ & $1,036.9 \mathrm{ab}$ & $1,351.2 \mathrm{a}$ & $1,490.5 \mathrm{a}$ & $958.0 \mathrm{tn}$ \\
\hline BNJ 0,01 & tn & tn & 416.1 & 373.5 & tn & tn \\
0,05 & tn & 129.1 & tn & tn & 250.9 & tn \\
\hline
\end{tabular}

Note: The numbers followed by different letters mean significant difference at the $\alpha=0.05$ and highly significant difference at $\alpha=0.01$. N1 $=$ New Guinea Teak, N2 = Gliciridia, N3 = White Teak P0 = No Pruning, P1 = One Pruning a month, $P 2=$ One pruning in two months, $t n=$ not significantly different, $m s p=$ weeks after treatment.

The shade loving trees play very complex and varied roles in drought mitigation as getting influenced by many factors. This information is very important as a comparison to observe the dynamics of sunlight intensity during $24 \mathrm{msp}$ in various cultivation conditions because each phase of plant growth varies to respond to stress. Another important factor is the type of plant when it grows individually and grows together with other plants (Sheng $-\mathrm{He}$ et al., 2005).

Table 4 below explains that the highest humidity value at $8 \mathrm{msp}$ is seen in New Guinea Teak (N1) of (87.54) and the lowest at $4 \mathrm{msp}$ in treatment (P2) of (65.03) but not significantly different from other treatments at $4 \mathrm{msp}, 12 \mathrm{msp}$ and $24 \mathrm{msp}$ both for three shade loving 
trees and for pruning time. Although it does not have a significant effect, microclimate conditions can be affected by the presence of shade loving trees, which generally support humidity, temperature, light and wind, thereby, reducing evapotranspiration (Wessel, 1971).

Table 4 - The Average of Humidity (RH, \%) on Three Types of Shade Loving Trees and Pruning Time on Cocoa Plants

\begin{tabular}{|c|c|c|c|c|c|c|}
\hline \multirow{2}{*}{ Treatment } & \multicolumn{5}{|c|}{ Average } & \\
\hline & $4 \mathrm{msp}$ & $8 \mathrm{msp}$ & $12 \mathrm{msp}$ & $16 \mathrm{msp}$ & $20 \mathrm{msp}$ & $24 \mathrm{msp}$ \\
\hline N1 & $64.80 \mathrm{tn}$ & 87.54 tn & 80.29 tn & 84.99 tn & $75.46 \mathrm{tn}$ & $79.59 \mathrm{tn}$ \\
\hline N2 & $64.93 \mathrm{tn}$ & $87.10 \mathrm{th}$ & $79.07 \mathrm{tn}$ & 86.00 th & $75.34 \mathrm{tn}$ & $80.79 \mathrm{tn}$ \\
\hline N3 & $64.93 \mathrm{tn}$ & $87.10 \mathrm{tn}$ & 80.28 tn & 84.79 tn & $76.10 \mathrm{tn}$ & $81.46 \mathrm{tn}$ \\
\hline BNJ 0,01 & tn & tn & tn & tn & tn & tn \\
\hline 0,05 & tn & tn & tn & tn & tn & tn \\
\hline P0 & $64.71 \mathrm{tn}$ & 87.48 th & $78.56 \mathrm{tn}$ & $86.62 \mathrm{a}$ & $76.54 \mathrm{a}$ & $81.22 \mathrm{tn}$ \\
\hline P1 & $64.92 \mathrm{tn}$ & 87.17 th & 81.40 th & $83.60 \mathrm{~b}$ & $76.68 \mathrm{a}$ & $79.51 \mathrm{tn}$ \\
\hline P2 & $65.03 \mathrm{tn}$ & $87.10 \mathrm{tn}$ & $79.68 \mathrm{tn}$ & $85.56 \mathrm{ab}$ & $73.68 \mathrm{~b}$ & $81.10 \mathrm{tn}$ \\
\hline BNJ 0,01 & tn & tn & tn & tn & 2.92 & tn \\
\hline 0,05 & tn & tn & tn & 2.71 & tn & tn \\
\hline
\end{tabular}

Note: The numbers followed by different letters mean significant difference at the $\alpha=0.05$ and highly significant difference at $\alpha=0.01$. N1 = New Guinea Teak, N2 = Gliciridia, N3 = White Teak P0 = No Pruning, P1 = One Pruning a month, $P 2=$ One pruning in two months, $t n=$ not significantly different, $m s p=$ weeks after treatment.

However, the same table shows that humidity is significantly different at $16 \mathrm{msp}$. (P0) is significantly different from (P1) but not significantly different from (P2) and has a very significant effect on $20 \mathrm{msp}$ on pruning time. (P0) is not significantly different from (P1) but is significantly different from (P2). In Figure 2, it can be seen that there is a relationship between the intensity of sunlight above and under the canopy and air humidity in a combination of treatments.
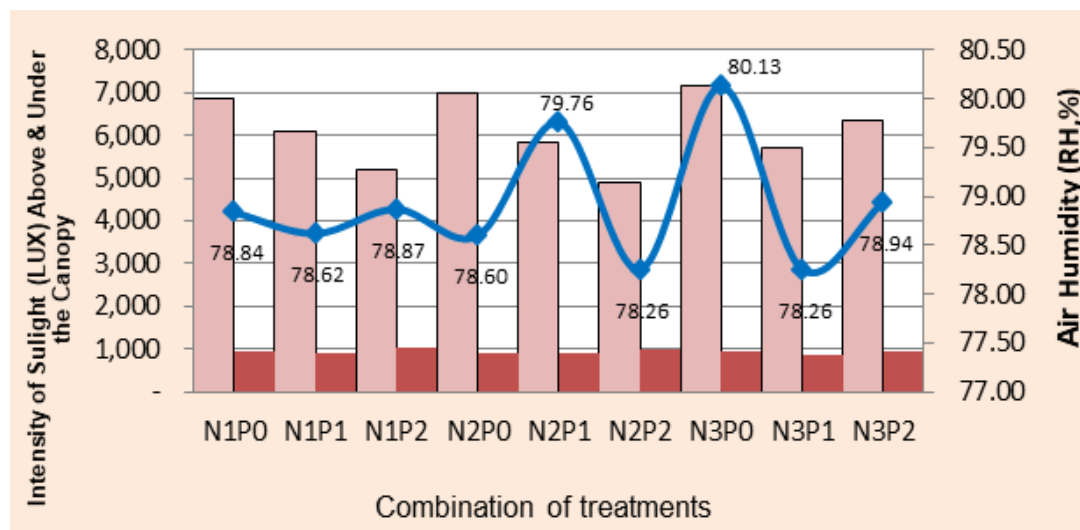

Figure 2 - The Dynamics of Sunlight Intensity Above and Under the Canopy (Lux) and Humidity $(\mathrm{RH}, \%)$ on Three Types of Shade Loving Trees and Pruning Time

The dynamics of humidity that occurred during the research were alleged to change in relative humidity in cocoa plantations, low relative humidity $(50-60 \%)$ or moderate $(70-80 \%)$ in the dry season dry season to high humidity (90-95\%) in the the beginning of the rainy season can induce flowering. In line with this, that humidity is related to the pressure of water vapor in the air either released through transpiration or evaporation, wind and temperature as well as linkages to the bottom of the plant canopy. Lack of light that reaches below the canopy causes approximately $87.54 \%$ humidity. shade plants do not directly affect the humidity of the air so they are pruned by pruning compared to plants that are not pruned (P0) will provide high humidity. There are indications that the structure and dynamics of cocoa agroecosystems influence microclimate (Beer, 1987). Besides, humidity is a factor that influences the formation of flush and flowering in cocoa plants (Hutcheon, 1977). 
The air temperature does not have significant differences on the three shade loving trees at the time of observation, as well as the observation on $4 \mathrm{msp}, 8 \mathrm{msp}$ and $12 \mathrm{msp}$, both for the three shade loving trees and for the pruning time. Furthermore, in Table 5, the air temperature does not have significant differences from the trimming time at $16 \mathrm{msp}$ where the treatment $(P 1)$ is significantly different from $(P 0)$ but not significantly different from (P2), also, at $20 \mathrm{msp}$, the treatment (P2) was significantly different from the treatment (P1) and (P0), then for $24 \mathrm{msp}$ treatment (P2) is significantly different from (P0) but not significantly different from (P1). Although there is no significant difference at $4 \mathrm{msp}$, the highest temperature value can be seen in the treatment (N3) in white teak (32.11) and treatment (P1) with the same value, as well as the observation on $8 \mathrm{msp}$ shows that lowest temperature is at (27.70).

Temperature is positively correlated with solar radiation, soil temperature and air temperature around the canopy. The temperature around the plant is determined by sunlight, plant density, light distribution in the plant canopy, soil moisture content, with one pruning a month or in every two months; it will have a positive effect on air and soil temperatures.

Table 5 - The Average of Air Temperature $\left({ }^{\circ} \mathrm{C}\right)$ on Three Types of Shade Loving Trees and Pruning Time on Cocoa Plants

\begin{tabular}{ccccccc}
\hline \multirow{2}{*}{ Treatment } & \multicolumn{7}{c}{ Average } \\
\cline { 2 - 7 } & $4 \mathrm{msp}$ & $8 \mathrm{msp}$ & $12 \mathrm{msp}$ & $16 \mathrm{msp}$ & $20 \mathrm{msp}$ & $24 \mathrm{msp}$ \\
\cline { 2 - 7 } $\mathrm{N} 1$ & $31.98 \mathrm{tn}$ & $27.70 \mathrm{tn}$ & $30.76 \mathrm{tn}$ & $30.08 \mathrm{tn}$ & $30.52 \mathrm{tn}$ & $30.01 \mathrm{tn}$ \\
$\mathrm{N} 2$ & $32.08 \mathrm{tn}$ & $27.97 \mathrm{tn}$ & $31.41 \mathrm{tn}$ & $29.56 \mathrm{tn}$ & $30.99 \mathrm{tn}$ & $30.36 \mathrm{tn}$ \\
$\mathrm{N} 3$ & $32.11 \mathrm{tn}$ & $27.92 \mathrm{tn}$ & $31.01 \mathrm{tn}$ & $30.21 \mathrm{tn}$ & $30.67 \mathrm{tn}$ & $31.31 \mathrm{tn}$ \\
\hline BNJ 0,01 & tn & tn & tn & tn & tn & tn \\
0,05 & tn & tn & tn & tn & $30.52 \mathrm{c}$ & $30.07 \mathrm{~b}$ \\
P0 & $32.03 \mathrm{tn}$ & $27.78 \mathrm{tn}$ & $30.89 \mathrm{tn}$ & $29.33 \mathrm{~b}$ & $30.53 \mathrm{bc}$ & $30.80 \mathrm{ab}$ \\
$\mathrm{P} 1$ & $32.11 \mathrm{tn}$ & $27.87 \mathrm{tn}$ & $30.84 \mathrm{tn}$ & $30.50 \mathrm{a}$ & $30.81 \mathrm{a}$ \\
$\mathrm{P} 2$ & $32.02 \mathrm{tn}$ & $27.94 \mathrm{tn}$ & $31.44 \mathrm{tn}$ & $30.11 \mathrm{ab}$ & $31.12 \mathrm{a}$ & tn \\
BNJ 0,01 & tn & tn & tn & tn & 0.58 & 1.25 \\
0,05 & tn & tn & tn & 0.89 &
\end{tabular}

Note: The numbers followed by different letters mean significant difference at the $\alpha=0.05$ and highly significant difference at $\alpha=0.01$. N1 $=$ New Guinea Teak, $N 2=$ Gliciridia, $N 3=$ White Teak $P 0=$ No Pruning, P1 = One Pruning a month, $P 2=$ One pruning in two months, $t n=$ not significantly different, $m s p=$ weeks after treatment.

Poorter et al (2013) states that the intensity of sunlight, CO2 and temperature determine sugar production, which is related to growth. Temperature has an effect on several important physiological processes, such as stomata openings, transpiration rate, rate of absorption of water and nutrients, photosynthesis and respiration. The increase in temperature is followed by this. In the following figure, we can see the intensity of sunlight above and under the canopy with air temperature and soil temperature.

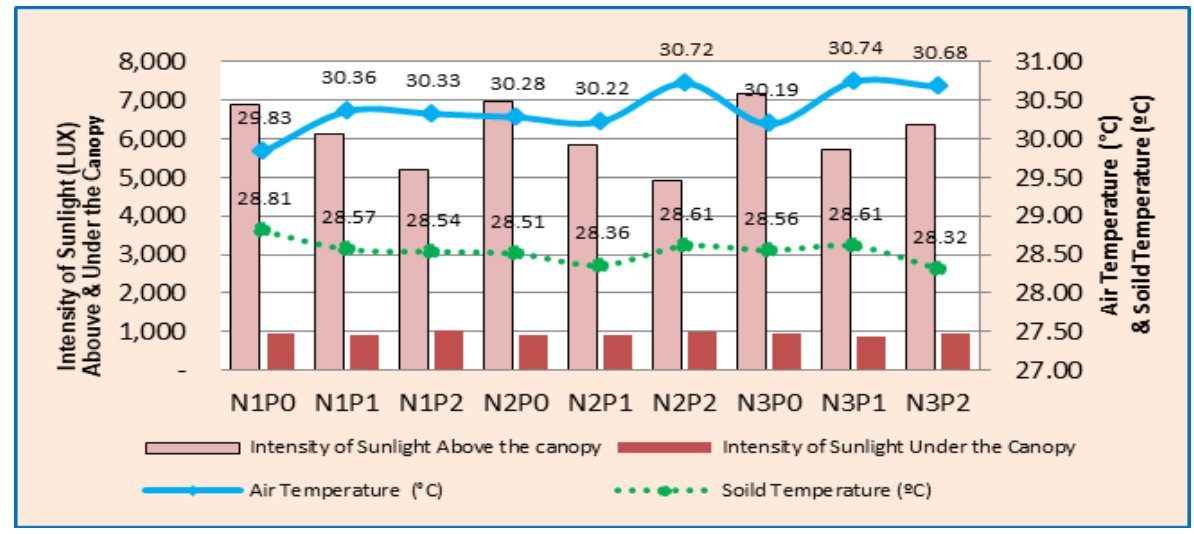

Figure 3 - The Dynamics of Sunlight Intensity Above and Under the Canopy and Air Temperature, Soil Temperature in Three Types of Shade Loving Trees and Pruning Time 
However, according to Snoeck et al (2010), the optimal average of monthly temperature is around $26^{\circ} \mathrm{C}-27^{\circ} \mathrm{C}$ for cocoa production. According to Daymond and Hadley (2004), temperature is one of the main limiting factors in cocoa production, because the temperature pressure has an effect on seasonal yields. The temperature difference in cocoa plantations measured outside and inside the canopy layer is around $\pm 0,5^{\circ} \mathrm{C}$ even though the higher temperature has been found in the dry season. The maximum temperature under the canopy varies from $1-3{ }^{\circ} \mathrm{C}$ from the average temperature under the canopy and the temperature difference in the canopy vary from $2,5-4{ }^{\circ} \mathrm{C}$,, while the maximum temperature above the canopy varies from 1,5 to $3,5^{\circ} \mathrm{C}$ (Miranda et al., 1994)

The description of Table 6 below shows that the observation interval provides an illustration and explains that the soil temperature is not significantly different from the three shade plants and pruning time at $4 \mathrm{msp}, 8 \mathrm{msp}, 12 \mathrm{msp}$ and $24 \mathrm{msp}$, but it is significantly different at $16 \mathrm{msp}$ with pruning time (P1) that is significantly different from (P2) but not significantly different from (P0). However, the same shows that there are interactions that occur between the three types of shade loving trees and pruning time to soil temperature at $20 \mathrm{msp}$ at the time of observation, and it can be explained that, white teak and one pruning in two months (N3P2) treatment are significantly different from other interactions in all treatments namely interactions (N3P1), (N3P0), (N3P1), and (N3P0). The highest soil temperature can be seen in the interactions between (N1P0), (N1P2), (N2P2) that is (28.67) while the lowest soil temperature can be seen in interaction (N3P2).

According to (Poorter and Van derwrf 1998), physiological interactions will be more complex if two or more environmental factors are involved. Canopy opening has an effect on micro-climate. There are indications that the structure and dynamics of agroecosystems have an effect on micro=climates (Beer, 1987). The interaction between three types of shade loving trees and pruning time to soil temperature indicates that the brown waste falling from three types of shade loving trees and penetration of sunlight with pruning time will improve micro-climate conditions, especially for soil temperature, soil erosion reduction, pests and diseases control, and increasing use of nutrients in cocoa plants and improving the physiological processes that occur in cocoa plants (Beer et al, 1998).

Table 6 - The Average of Soil Temperature $\left({ }^{\circ} \mathrm{C}\right)$ on Three Types of Shade Loving Trees and Pruning Time on Cocoa Plants

\begin{tabular}{cccccc}
\hline \multirow{2}{*}{ Treatment } & \multicolumn{5}{c}{ Average } \\
\cline { 2 - 6 } & $4 \mathrm{msp}$ & $8 \mathrm{msp}$ & $12 \mathrm{msp}$ & $16 \mathrm{msp}$ & $24 \mathrm{msp}$ \\
\hline N1 & $32.43 \mathrm{tn}$ & $26.56 \mathrm{tn}$ & $29.78 \mathrm{tn}$ & $27.33 \mathrm{tn}$ & $27.39 \mathrm{tn}$ \\
$\mathrm{N} 2$ & $32.39 \mathrm{tn}$ & $26.56 \mathrm{tn}$ & $29.44 \mathrm{tn}$ & $27.22 \mathrm{tn}$ & $27.30 \mathrm{tn}$ \\
$\mathrm{N} 3$ & $32.69 \mathrm{tn}$ & $26.78 \mathrm{tn}$ & $29.78 \mathrm{tn}$ & $27.33 \mathrm{tn}$ & $26.83 \mathrm{tn}$ \\
\hline BNJ 0,01 & tn & tn & tn & tn & tn \\
0,05 & tn & tn & tn & tn & tn \\
\hline P0 & $32.67 \mathrm{tn}$ & $26.56 \mathrm{tn}$ & $29.72 \mathrm{tn}$ & $27.33 \mathrm{ab}$ & $27.36 \mathrm{tn}$ \\
P1 & $32.24 \mathrm{tn}$ & $26.67 \mathrm{tn}$ & $29.61 \mathrm{tn}$ & $27.56 \mathrm{a}$ & $27.22 \mathrm{tn}$ \\
P2 & $32.60 \mathrm{tn}$ & $26.67 \mathrm{tn}$ & $29.67 \mathrm{tn}$ & $27.00 \mathrm{~b}$ & $26.94 \mathrm{tn}$ \\
\hline BNJ 0,01 & tn & tn & tn & tn & tn \\
0,05 & tn & tn & tn & 0.42 & tn \\
\hline
\end{tabular}

Note: The numbers followed by different letters mean significant difference at the $\alpha=0.05$ and highly significant difference at $\alpha=0.01$. N1 = New Guinea Teak, N2 = Gliciridia, N3 = White Teak $P 0=$ No Pruning, P1 = One Pruning a month, $P 2=$ One pruning in two months, $(a, b)$ shows the differences in pruning time on three types of shade loving trees. $(x, y)$ shows the difference of effect in certain type of shade loving trees on pruning time.

Climate has a great effect on brown waste from the shade loving and cocoa trees that shed their leaves in the dry season. Maximum brown waste is on low rainfall period or when entering a dry season (Ling, 1986), as occurred in interaction (N3P2).

The explanation in Table 7 below illustrates that the three types of shade loving trees have a significant effect on the leaf moisture, but the pruning time is not significantly different. However, even though it is not significantly different, it can be seen that the highest leaf moisture is in treatment (P1) with a value of (84.97). The existence of a significant effect on 
three types of shade plants on leaf moisture can be explained that the treatment (N1) is significantly different from the treatment (N2) but not significantly different from the treatment (N3). For the observation on leaf temperature, in the same table, it can be seen that, the pruning time is significantly different from the leaf temperature, but the three types of shade loving trees are not significantly different. Although it is not significantly different but the highest leaf temperature value can be seen in the treatment (N3) with a temperature of (31.04). It is thought that this is due to different climatic conditions from three different shade loving trees. Another factor that influences is the weather conditions is the time of measurement. In cocoa plantations that experience changes in relative humidity, from relatively low humidity (50-60\%) or moderate $50-60 \%$ in the dry period during the dry season because shade loving trees compete with cocoa trees in utilizing water, nutrients and light (Bonaparte, 1975).

Furthermore, the explanation of the significant effect that occurs with the pruning time to leaf temperature shows that treatment (P2) is significantly different from (P0) but not significantly different from (P1). Pruning can reduce the internal competition of plants for photosynthesis compared to the trees that are not pruned (P0) will be more lush and competition occurs between one leaf with another. The temperature around the plants is determined by sunlight, plant density, light distribution in the plant canopy and soil moisture content also have an effect on leaf temperature. Leaf orientation has an effect on leaf temperature which in turn has an effect the rate of transpiration and water use efficiency. Vertical cocoa leaf orientation can reduce radiation interception, so leaves are cooler and water loss may be limited when compared to the horizontal leaf orientation (Abo-Hamed et al., 1983).

Table 7 - The Average of Leaf Moisture (\%), Leaf Temperature $\left({ }^{\circ} \mathrm{C}\right)$ Chlorophyl Index, Leaf Area $\left(\mathrm{cm}^{2}\right)$, Photosynthesis Rate $\left(\mathrm{mmol} \mathrm{m}^{-2}\right)$ on Three Types of Shade Loving Trees and Pruning Time in Cocoa Plants

\begin{tabular}{|c|c|c|c|c|}
\hline \multirow{2}{*}{ Treatment } & \multicolumn{3}{|c|}{ Average } & \\
\hline & Leaf Moisture & Leaf Temperature & Chlorophyll Index & Leaf Area \\
\hline N1 & $84.89 \mathrm{a}$ & $30.32 \mathrm{tn}$ & $65292.2 \mathrm{tn}$ & $2,244.5 \mathrm{tn}$ \\
\hline N2 & $81.89 \mathrm{~b}$ & 30.73 tn & 64875.1 th & $2,662.7 \mathrm{tn}$ \\
\hline N3 & $83.98 \mathrm{ab}$ & $31.04 \mathrm{tn}$ & 64430.9 tn & $2,258.5 \mathrm{tn}$ \\
\hline BNJ 0,01 & tn & $\operatorname{tn}$ & tn & tn \\
\hline 0,05 & 2.83 & tn & tn & tn \\
\hline P0 & $83.37 \mathrm{tn}$ & $30.18 b$ & 65078.0 tn & $2,233.7 \mathrm{tn}$ \\
\hline P1 & 84.97 tn & $30.92 \mathrm{ab}$ & 64995.9 tn & $2,708.9 \mathrm{tn}$ \\
\hline P2 & $82.42 \mathrm{tn}$ & $31.01 \mathrm{a}$ & 64524.4 tn & $2,229.1 \mathrm{tn}$ \\
\hline BNJ 0.01 & tn & $\operatorname{tn}$ & $\operatorname{tn}$ & tn \\
\hline 0.05 & tn & 0.85 & tn & tn \\
\hline \multirow[t]{2}{*}{ Treatment } & \multicolumn{3}{|c|}{ Average Photosynthesis Rate } & \\
\hline & $\mathrm{PO}$ & $\mathrm{P} 1$ & P2 & BNJ 0.05 \\
\hline N1 & $\begin{array}{c}21.35 b \\
Y\end{array}$ & $\begin{array}{c}21.70 \mathrm{~b} \\
\mathrm{Xy}\end{array}$ & $\begin{array}{c}21.97 \mathrm{a} \\
\mathrm{x}\end{array}$ & 0.63 \\
\hline N2 & $\begin{array}{c}22.48 \mathrm{a} \\
\mathrm{X}\end{array}$ & $\begin{array}{c}22.53 \mathrm{a} \\
\mathrm{X}\end{array}$ & $\begin{array}{c}22.52 \mathrm{a} \\
\mathrm{x}\end{array}$ & \\
\hline N3 & $\begin{array}{c}22.70 \mathrm{a} \\
\mathrm{X}\end{array}$ & $\begin{array}{c}22.30 \mathrm{ab} \\
\mathrm{Xy}\end{array}$ & $\begin{array}{c}21.95 \mathrm{a} \\
y\end{array}$ & \\
\hline $\begin{array}{c}\text { BNJ } 0.01 \\
0.05\end{array}$ & $\begin{array}{c}\text { tn } \\
0.63\end{array}$ & & & \\
\hline
\end{tabular}

Note: The numbers followed by different letters mean significant difference at the $\alpha=0.05$ and highly significant difference at $\alpha=0.01$. N1 = New Guinea Teak, N2 = Gliciridia, N3 = White Teak P0 = No Pruning, P1 = One Pruning a month, $P 2=$ One pruning in two months, $(a, b)$ shows the differences in pruning time on three types of shade loving trees. $(x, y)$ shows the difference of effect in certain type of shade loving trees on pruning time.

The low chlorophyll content and high anthocyanin pigment in expanding leaves also play a role in maintaining relatively low leaf temperatures and, together with a relatively dense layer of hair on the leaf surface, which can be a cause of decreased transpiration rates 
(Abo-Hamed et al., 1983). It can be seen on the following figure that there is photosynthesis rate, leaf temperature and leaf moisture against the treatment combination.
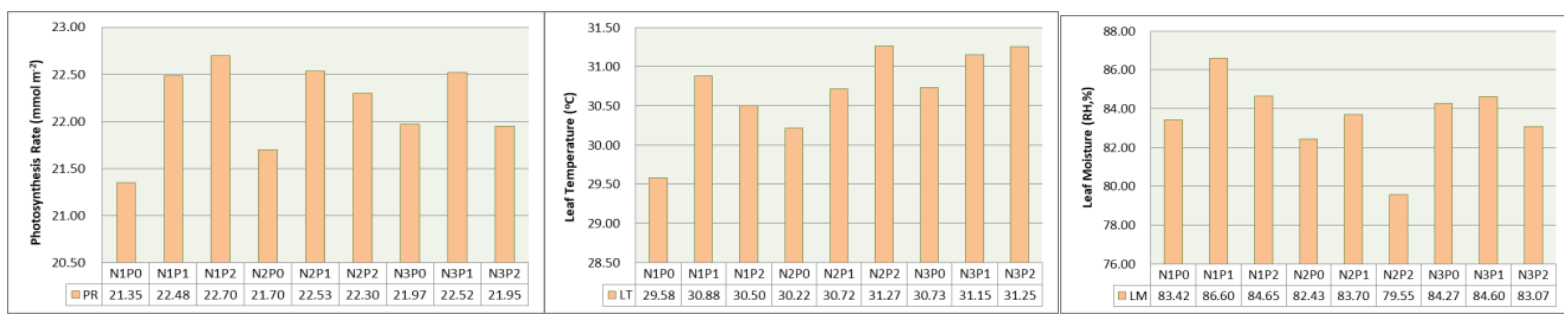

Figure 4 - The Dynamics of Photosynthesis Rate, Leaf Temperature and Leaf Moisture in Three Types of Shade Loving Trees and Pruning Time

The effect of interactions that occurs between three types of shade loving trees and pruning time on the observation of photosynthesis rate can be seen in Table 7. It shows that the interaction between (N2P1) is significantly different from (N1P0), (N1P1) and (N3P1) but not significantly different from (N2P2), (N3P2), (N1P2), (N3P0) and (N2P0). Furthermore, interaction between (N1P2) is significantly different from (N1P0), (N1P1). Interaction (N3P0) is significantly different from interaction (N3P1) but not significantly different from (N3P2). In the same table it can be seen that the highest value of the rate of photosynthesis in is interaction (N2P2) with a value of (22.57) and the lowest rate of photosynthesis is in interaction (N1P0) with a value of (21.35). The interaction that occurred with the rate of photosynthesis was greatly influenced by the type of shade loving trees and pruning time. Different types of shade loving trees and different pruning times have a good effect compared to no pruning treatment. Penetration of sunlight in the presence of different shade loving trees plants and pruning times has a direct effect on the rate of photosynthesis. Intensity is the amount of energy received by plants in certain area and time period. The intensity of sunlight has an effect on the physiological properties of plants.

Leaves that grow under the decrease in photosynthesis rate occur under $20 \%$ full sunlight (Owusu, 1978). Meanwhile, according to Okali and Owusu (1975), the shaded leaves, the level of light reception received is around $3-4 \%$ full sunlight. Therefore, variations in reception of light intensity must be a reflection of differences in growth and measurement conditions. If the nutritional needs of plants are met, plant growth is mainly dependent on access to solar radiation (Cunningham and Arnold, 1962).

Table 8 - The Average of Number of Fruits, Fresh Weight of 100 Seeds (gram), Dry Weight of 100 Seeds (gram) on Three Types of Shade Loving Trees and Pruning Time in Cocoa Plants

\begin{tabular}{cccc}
\hline Treatment & \multicolumn{3}{c}{ Average } \\
\cline { 2 - 4 } & Number of Fruits & Fres Weight of 100 seeds & Dry Weight of 100 Seeds \\
N1 & $9.00 \mathrm{~b}$ & $97.56 \mathrm{tn}$ & $44.62 \mathrm{tn}$ \\
$\mathrm{N} 2$ & $9.94 \mathrm{ab}$ & $104.50 \mathrm{tn}$ & $40.72 \mathrm{tn}$ \\
$\mathrm{N} 3$ & $12.00 \mathrm{a}$ & $101.56 \mathrm{tn}$ & $41.44 \mathrm{tn}$ \\
\hline BNJ 0.01 & $\mathrm{tn}$ & $\mathrm{tn}$ & $\mathrm{tn}$ \\
0.05 & 2.09 & $\mathrm{tn}$ & $\mathrm{tn}$ \\
\hline P0 & $9.00 \mathrm{~b}$ & $82.61 \mathrm{~b}$ & $44.06 \mathrm{~b}$ \\
P1 & $10.06 \mathrm{a}$ & $105.72 \mathrm{a}$ & $53.28 \mathrm{a}$ \\
P2 & $11.89 \mathrm{a}$ & $115.28 \mathrm{a}$ & tn \\
\hline BNJ 0.01 & tn & 19.10 & 15.68 \\
BNJ 0.05 & 2.09 & tn &
\end{tabular}

Note: The numbers followed by different letters mean significant difference at the $\alpha=0.05$ and highly significant difference at $\alpha=0.01$. N1 $=$ New Guinea Teak, $N 2=$ Gliciridia, $N 3=$ White Teak $P 0=$ No Pruning, $P 1=$ One Pruning a month, $\mathrm{P2}=$ One pruning in two months, th = not significantly different.

The results of BNJ test at $\alpha=0.05$ and $\alpha=0.01$ in Table 8 illustrate that the three types of shade loving trees and pruning time are significantly different on the number of fruits per tree. Treatment (N3) is significantly different from treatment (N1) but not significantly different 
with (N2), while the effect of pruning time explains that the treatments (P2) and (P1) are not significantly different but both are significantly different from (P0). Furthermore, for the wet weight of 100 seeds, the three types of shade loving trees are not significantly different but the pruning time is very significantly different. Treatments (P2) and (P1) are not significantly different from the pruning time but are very significantly different from (P0). For the dry weight of 100 seeds, three types of shade loving trees are also not significantly different, but the pruning time is significantly different, and it was determined that treatments (P2) and (P1) are not significantly different but are significantly different from treatment (P0).

The types of shade loving trees and pruning time play a role in controlling environmental factors and determining plant development such as the agronomic aspects (the number of fruits and fresh and dry weight of 100 seeds). Changes in micro-climate are due to shade loving trees and pruning time. The level of sunlight intensity receipt has significantly effect on the growth and production of cocoa plants. The cocoa production cycle follows a seasonal pattern depending on the rainy season, especially for rainfall. As explained earlier that the distribution of rain is more important than the amount of rainfall, which is very influential on cocoa production.

In some cocoa producing centers, including Indonesia, rainfall is not evenly distributed throughout the year, and in some months where rainfall does not exceed $100 \mathrm{~mm}$. This fact resulted in the growth and production of cocoa pods not being continuous (Wood, 1985a; $1985 b)$. The following figure shows the effect of the treatment on the number of fruits, fresh weight of 100 seeds and dry weight of 100 seeds.

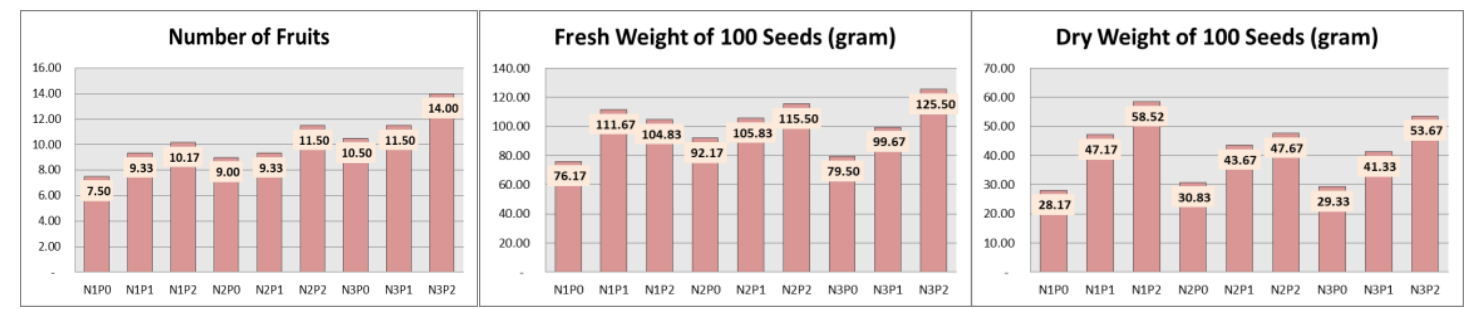

Figure 5 - Number of Fruits, Fresh Weight of 100 Seeds (gram), Dry Weight of 100 Seeds (gram) on Three Types of Shade Loving Trees and Pruning Time in Cocoa Plants

In addition, the flush formation is another influencing factor. Flushing usually occurs in a 6-8 week cycles (Asomaning, Kwakwa and Hutcheon, 1971). According to Almeida and Valle (2008) that a new flush is formed immediately after the supply of carbohydrates is met again after the previous flush which can be associated with the impact of environmental conditions such as sunlight intensity, temperature, and soil moisture (Asomaning, Kwakwa and Hutcheon, 1971). Flush cycles, although influenced by environmental factors, are still governed internally, and also occur in constant environmental conditions (Almeida and Valle, 2008). However, it seems that flush is relatively unaffected by other aspects of growth, on the contrary, some level of control over flush growth can lead to more efficient pod production.

The fruit is very closely related to the young fruit formed called "cherelles", or "pentil" in Indonesia. During the first 50-100 days after fruit set, the growth of the young fruits can stop, and the cherelles then turn into yellow, contracted and blackened. The degree of wilting may be due to intense competition in the use of carbohydrates and mineral nutrients between cherelles and between the cherelles and the development of leaf maturation. According to Asomaning, Kwakwa and Hutcheon (1971) and Wassel (1971), that an increase in wilting at or immediately after a leaf flush, supports the notion that nutritional competition as the cause. According to Zuidema et al., (2005) differences in production are influenced by differences in crop management. Large productivity variables can be found between years and among trees of the same population. Variability can be reduced by providing optimal growth conditions (Bartley, 1970). Pruning to increase yields can reduce yield variability among trees and increase crop productivity. Besides, climatic conditions are very important in determining the results that can be achieved (Rabbinge 1993; Zuidema et al., 2005). 


\section{CONCLUSION}

The type of shade loving trees has an effect on the intensity of sunlight above the canopy at $24 \mathrm{msp}$, and it does not have any effect on other weather aspects. The physiological aspects have an effect on the leaf moisture. The highest leaf moisture was found in New Guinea Teak (N1), White Teak (N3) and Gliciridia (N2), respectively, but the agronomic aspects of shade loving trees have an effect on the number of fruits.

Pruning time has an effect all aspects of the weather; intensity of sunlight above the canopy at $8 \mathrm{msp}, 16 \mathrm{msp}$ and $20 \mathrm{msp}$ and below the canopy at $8 \mathrm{msp}, 12 \mathrm{msp}, 16 \mathrm{msp}$ and $20 \mathrm{msp}$, humidity at $16 \mathrm{msp}$ and $20 \mathrm{msp}$, air temperature at $16 \mathrm{msp}, 20 \mathrm{msp}$ and $24 \mathrm{msp}$, and on soil temperature at $16 \mathrm{msp}$. For the physiological aspects, pruning time has a positive effect on leaf temperature in (P2) treatment, more positive than (P1) and (P0). For the agronomic aspects, the pruning time has a positive effect on the number of fruits, and fresh and dry weight of 100 seeds in (P2) treatment better than (P1) and (P0).

The interaction between shade loving trees and pruning time has an effect on the soil temperature and photosynthesis rate. The interaction between White Teak and one pruning in two months (N3P2) gave the lowest temperature (26.83) compared to other interactions. Furthermore, interaction between Gliciridia and one pruning in two months gave the highest photosynthesis rate (22.57) and the lowest photosynthesis rate was in interactions between New Guinea Teak without pruning (N1P0) with a value of (21.35).

\section{REFERENCES}

1. Abdoellah, S. and Soedarsono, 1996. Penaung and Pemangkasan Kakao; Suatu Tinjauan dari Aspek Iklim Mikro and Kesuburan Tanah, Warta Pusat Penelitian Kopi and Kakao 12, 153-160.

2. Abo-Hamed S, Cllin HA, Hardwick K. 1983. Biochemical and Physiological Aspects of Leaf Development in Cocoa (Theobroma cacao L.). VII Grwth, Orientation, Surface Structure and Water Loss from Developing Flush Leaves. New Phytol. 95:9-17.

3. Almeida A-A F. Valle R R. 2008. Ecophysiology of the Cacao Tree. Departemento de Ciencias Biologicas, Universidade Estadual de Santa Cruz 45662-000 liheus, BA, Brasil. Centrode Pesquisas do Cacau, CEPLAC, C.P. 07, 45650-000 liheus, BA, Brasil.

4. Alvim, P. Physiological Responses of Cocoa to Enviromental Factor. IV int. Cocoa Res. Conf. St. Augustine, Pp 210-225.

5. Alvim, R.P. de T Alvim, R Lorenzi, and P.F Saanders, 1974, The Possible Role of Absisic Acid and Cytokinius in Growth Rhytms of TheobromaCacao L. Rev. Theobroma Venezuela.

6. Asomaning, E., Kwakwa, R. And Hutcheon, W. 1971. Physiological Studies on an Amazon Shade and Fertilizer Trial at the Cocoa Research Institute of Ghana. Ghana J of Agricultural Science, 4, 47-64.

7. Atanda OA., 1972. Correlation Studies In Theobroma cacao L. Turrialba 22:81-89.

8. Baihaqi A, A. H. Hamid, A. Anhar, Y. Abubakar, T. Anwar, Y, Zazunar, 2015. Penerapan Teknik Budidaya Serta Hubungan Antara Pemangkasan and Peningkatan Kesuburan Tanah Terhadap Peningkatan Produktivitas Kakao Di Kabupaten Pidie. Agrisep Vol (6) No. 2.

9. Bartley, B. 1970. Yield Variation in The Early Productive Years in Trials With Cacao (Theobroma cacao L) Euphytica, 19, 199-206.

10. Beer, J. 1987. Adventages, Disadvantages and Desirable Characteristics of Shade Trees for Coffee, Cacao and Tea. Agroforestry System, 5: 3-13.

11. Beer, J., Muschler, R., Kass, D. and Somaribba, E. 1998. SHADE Management in Coffee and Cacao Plantations. Agroforestry System, 38, 139-164.

12. BMKG, 2018. Data Curah Hujan Lima Tahun, Badan Meteorologi Klimatologi and Giofisika Wilayah IV Makassar.

13. Bonaparte EENA. 1975. Yield Gradients in Cocoa (Theobroma cacao L) Shade and Fertilizer Experiments. Acta Hort 49:251-257. 
14. BPS, 2014. Sulawesi Selatan Dalam Angka 2014. Biro Pusat Statistik Provinsi Sulawesi Selatan.

15. BSN, 2008. Standar Nasional Indonesia Biji Kakao 2323: 2008 http://sisni.bsn.go.id/index.php/sni_main/sni/detail_sni/7763.(19 Mei 2014).

16. Cunningham, R. and Arnold, P. 1962. The Shade and Fertiliser Requirements of Cacao (Theobroma cacao L) in Ghana. Journal of the Science of Food and Agriculture, 13. 213221.

17. Daymond, A. J. and Hadley, P. 2004. The Effect of Temperature and Light Integral on Early Vegetative Growth and Chlorophyll Fluorescence of Four Contrasting Genotypes of Cacao (Theobroma cacao L). Annals of Applied Biology 145:257-262.

18. Direktorat Jenderal Perkebunan, 2013. Statistik Perkebunan 2009-2011 Pusat Data and Informasi Pertanian, Kementrian Pertanian. Jakarta.

19. Fatmawati, Ariffin, S. Y. Tyasmoro, R. Sulistyono, 2018. Sun Light Intensity Identification In Cocoa Plant On Variation Of Shading Plant Type In Soppeng Regency. J. of Scentific \&Tecnology Research ISSN 2277-8618 (7) 205-210.

20. Hutcheon, W. V. 1977. Growth and Photosynthesis of Cocoa in Relation to Enviromental and Internal Factors In Proc. 5 th int. Cooa Res. Conf., Ibadan, Nigeria, pp. 222-232.

21. ICCO, 2015. ICCO Quaterly Bulletin of Coca Statistics, Vol XLI, No. 2, Cocoa years 2014/2015.

22. Ling, A.H. 1986. Litter Production and Nutrient Cycling in a Mature Cocoa Plantation on Inland Soils of Peninsure Malaysia. In "Proc. Int. Conf. Cocoa and Coconuts, Kuala Lumpur" (E. Pushparajah and C.P. Soon, Eds.), pp. 451-465.

23. Owusu JK. 1978. Light Requirements of Cocoa: A Review. In: Proc. Int. Conf. Cocoa and Coconuts, Kuala Lumpur, Malaysia, pp. 112-121.

24. Prawoto, A. A. 2012. Impact of Teak (Tectonia grandis Linn) Thinning Out and Peacockplume $\{($ Paraseriantthes falcataria L.) I Neilsen)\} harvesting on Mineral Cycle, Pod Rot Incidence, Changing of Cocoa Yield, and land Productivity in Indonesia. J. of Agric Scien and Tech A, 2, 438-448.

25. Poorter, H. Niels P.R.A and Leo F.M.M., 2013. Physiological Mechanisms in Plant Growth Models: Do We Need a Supra-Cellular Systems Biology Approach. Plant cell and Environmen, 36. 1673-1690.

26. Rabbinge, R. 1993. The Ecologikcal Background of food Production. Crop Protection and Sustainabel Agroculture, Ciba Foundation Symposium 177, pp 2-29 John Wiley, Chichester.

27. Sheng-He. JS, Zhang QB, Bazzaz, F.A. 2005. Differential Drought Responses between Saplings and Adult Trees in Four Co-Occurring Species of New England Trees 19:442450.

28. Siregar, T.H.S., S. Riyadi, and L. Nuraeni, 2003. Pembudidayaan, Pengolahan and Pemasaran cokelat. Penebar Swadaya, Jakarta.

29. Snoeck, D., Afrifa, A., Ofari Frimpong, K., Boateng, E. and Abekoe, M. 2010. Mapping Fertilizer Recommendations for Cocoa Production in Ghana Using Soil Diagnostic and GIS tools. West African Journal if Applied Ecology, 17; 97-107.

30. Suryani, Dinie and Zulfebriansyah, 2007. Komoditas kakao. Potret and peluang Pembiayaan didalam Economic. Rev No. 210. P. 9.

31. Wessel, M. 1971. Fertilizer Requirements of Cocoa (Theobroma cacao L.) in SouthWestern Nigeria. Communication 61, pp 104. Amsterdam; Koninklijk Institut voor de Tropen.

32. Wood, G.A.R. 1985a. Environment. Chapter 3 in Cocoa $4^{\text {th }}$ Edition (Eds G. A.R. Wood and R. A. Lass). Oxford, Blackwell Science, 38-39.

33. Wood, G. A. R. 1985b. From Harvest to Store. In Cocoa $4^{\text {th }}$ Edition 444-504 (Eds. G.A.R. Wood and R. A. Lass) Oxford, Blackwell Science.

34. Zuidema P.A., Leffelaar P.A., Gemitsma W., Mommer L., Anten NPR, 2005. A Physiological Production Model for Cocoa (Theobroma cacao L) Model Presentation, Validation and Application. Agric: Syst. 84: 195-225. 